\title{
Integrity of the benchmark price for price testing of US municipal bonds*
}

\author{
Srečko Devjak ${ }^{1}$
}

\begin{abstract}
External financial market data institutions (vendors) may provide different prices for the same US municipal bond due to differences among market participants in perception about its market value. The valuation control function will include only selected vendors in the calculation of the consensus price, which enters as a benchmark price in the price testing process. Selection of vendors is largely driven by the valuation control function's consideration of their valuation capabilities and their market coverage. Empirical analysis in this paper shows that additional pricing service may bring additional pricing information to the final consensus price, which may significantly alter the benchmark price and final price testing results. The approach described in this paper is in interest of any financial institution with US municipal bonds in the trading portfolio. Contribution of this paper to valuation of US municipal bonds is high because remaining literature does not explain alternative approach to measurement of additional pricing information in the benchmark price.
\end{abstract}

Key words: investment banking, US municipal bonds, valuation risk management, market efficiency, calculation of a benchmark price

JEL classification: G12, G14, G24, G32, C81

\section{Introduction}

A municipal bond is a fixed or a floating rate bond issued by a state (as part of a federal country), city or other local government, or their agencies and subdivisions. They fall in two categories, general obligations and revenue bonds. Because interest on most of these securities is exempt from taxation at the federal level

\footnotetext{
* Received: 07-03-2020; accepted: 22-05-2020

1 Assistant professor, iMentor, Velika Slevica 21, SI- 1315 Velike Lašče, Slovenia. Scientific affiliation: treasury risk management in banking, quant engineering in banking. Phone: +38640850090.E-mail:dr.S.Devjak@gmail.com. Personal website: https://www.linkedin.com/ in/dr-srecko-devjak-83048025/
} 
and sometimes at state and local levels, they are also called tax exempt bonds. Municipal bonds can further be classified into two clusters, high-grade and highyield municipal bonds. High-yield refers to non-investment grade or unrated municipal bonds, whereas high-grade refers to investment grade municipal bonds.

Financial institutions value their trading portfolios in front office and book obtained valuation results in the general ledger. To ensure that the general ledger reflects only fair value of trading portfolios, an independent valuation control function values the same trading portfolios again and calculates valuation adjustments, which are also booked in the general ledger. As a result, the general ledger will reflect trading portfolios at fair value.

The valuation process is composed of sub-processes, which are classified into two groups, price testing processes and processes for calculation of valuation adjustments. Since price of a municipal bonds by itself already reflects fair value of this asset on the market at which market participants are willing to do a transaction, the valuation control function does not further adjust this price with valuation adjustments. Hence, the only adjustment that comes out of the valuation process of a municipal bond, is the price testing adjustment or pricing adjustment.

The valuation control function values trading portfolio of municipal bonds on a CUSIP level. CUSIP is an acronym that refers to Committee on Uniform Security Identification Procedures and is a nine-digit numeric or nine-character alphanumeric code, which is used to identify securities, including municipal bonds. The valuation control function values municipal bonds at least at month-end and sends valuation results to financial control function, which books valuation results in the general ledger. In ideal scenario, the valuation control function values trading portfolio on a daily basis, which provides a better control and overview over fair value of the trading portfolio over time for the senior management.

To complete the valuation process, the valuation control function needs three inputs, end-of-day portfolio structure, front office prices and external prices for municipal bonds in the trading portfolio. The valuation control function obtains portfolio structure from the product control function, which ensures population completeness of a trading portfolio in focus of valuation. Requirement for population completeness is met if end-of-day portfolio structure contains all CUSIPs and if accurate notional values are assigned to these CUSIPs. The product control function is not only responsible to ensure population completeness of a trading portfolio in focus for valuation, it is also responsible to ensure accurate front office prices for each CUSIP. The valuation control function on the other hand is responsible for importing complete and accurate external prices for each CUSIP.

In this paper we study information completeness of the final consensus price, which enters as a benchmark price in the price testing process of US municipal bonds. Specifically, we explore amount of additional information, which enters in the 
final consensus price with additional pricing service. Calculation of the consensus price, which enters in the price testing process, is responsibility of the valuation control function because valuation control function is also responsible for correct calculation of the pricing adjustments. Too little pricing services in the consensus price make consensus price unreliable because the consensus price in this case does not holistically reflect opinion of the market about the fair market price of the municipal bond. Such consensus price is then also less appropriate to enter in the price testing process as a benchmark price, against which the valuation control function compares front office prices of municipal bonds in order to calculate pricing adjustments that move portfolio value in the general ledger from front office value to fair value, which is in interest of the management, shareholders and ultimately of regulators.

Every additional pricing service in the consensus price improves reliability of the consensus price and makes it more appropriate as the benchmark price. However, every additional pricing service brings additional cost to the owner of a trading portfolio in line with the price list of vendor, which provides additional pricing service in focus. The question is, how many pricing services should enter in calculation of the consensus price so that the final consensus price will qualify itself as an appropriate benchmark price for the price testing process. Our hypothesis is that the valuation control function should consider additional pricing service in the consensus price as long as additional pricing service significantly alters the final consensus price. Our hypothesis also is that the amount of additional information from additional pricing service is significant, if the post-threshold pricing adjustment based on the consensus price with additional pricing service is significantly different from the post-threshold pricing adjustment based on the consensus price without additional pricing service.

Selection of vendors and pricing services is thus an optimization problem, where owners of trading portfolios collect given amount of pricing information from vendors for a minimal cost. Investment banks as portfolio owners will consider a number of the most reputable vendors to obtain relevant pricing services for calculation of the final consensus price. However, selected number of reputable vendors and pricing services may not be sufficient to achieve information completeness of the final consensus price, that should enter into the price testing process. This is a practical problem of the valuation control function, which needs a sound solution to justify the post-threshold pricing adjustments and linked records in the general ledger. This paper contributes to economic science with an answer on a question, which pricing services should the valuation control function consider to include in the final consensus price and how many pricing services should the valuation control function ultimately include in the calculation of the final consensus price. We will provide an answer to this question by proving or not proving our working hypothesis, which we explained earlier. 
The rest of this paper is organized as follows. Section two contains review of literature, which deals with valuation of municipal bonds. Section three explains the model, which we will use to work with the data and to find an answer to the research questions. Section four explains empirical data, which we will use in this research. The results are interpreted in section five. Section six explains conclusions.

\section{Literature review}

Pricing of municipal bonds has been previously researched by many authors and from various aspects. Authors have researched pricing of plain vanilla municipal bonds as well as valuation of municipal bonds with embedded options. Result of their work is usually a methodology, which is improved in comparison to existing methodologies. Risk aversion is an important preference of investors at selection of investments, therefore Kriz (2004) tested the presence of risk aversion on the municipal bond market and found a significant level of risk aversion at trading with municipal bonds, which drives the pricing of municipal bonds. He tested for the presence of risk aversion on the municipal bond market through comparison of yields from a risk-neutral bonds and yields from municipal bonds. Partridge and Medda (2020) have studied another sentiment of investors, this is their inclination towards nature preservation. Specifically, they have investigated the performance of US green municipal bonds in comparison with general municipal bonds. To achieve research results, they selected two metrics to assess performance of US green municipal bonds. The first metric was the green municipal bond index and the second metric was the difference in yields between green municipal bonds and their conventional counterparts. Research has shown that pricing of municipal bonds on the secondary market is sensitive to embedded green component in municipal bonds. Empirical results have shown that an index comprised of green municipal bonds outperforms the closest equivalent S\&P index from 2014 to 2018. Moreover, there is a statistically significant green premium present in the secondary muni bond market of 5 basis points by 2018 .

Some authors research pricing of municipal bonds based on comparison with corporate bonds. In this way, Fama (1977) explains that US municipal bonds have relatively higher yield in comparison to corporate and governmental bonds because municipal default risk exceeds the default risk of corporate and governmental bonds. Defaults on municipal bonds in the history have raised concern about the credit risk of municipal bonds. Between 1977 and 1998, 1.765 out of a total of 253.850 issues of municipal bonds defaulted, with a face value of $\$ 24,9$ billion out of a total of $\$ 375,5$ billion (see Litvack and Rizzo, 2000). Wang et al. (2008) hence conclude that the probability of default may not be trivial and is of potentially greater concern for low-rated uninsured municipals. 
Wang et al. (2008) also showed that prices of municipal bonds are strongly driven by liquidity, default and personal taxes. A similar research has been done by Lin et al. (2009). They have studied an effect of liquidity risk on relative yields of municipal and taxable bonds. For this reason, they have employed a reducedform model with liquidity intensity and taxes to price tax-exempt bonds. Results show that a substantial portion of the yield spread between municipal and taxable bonds is attributable to the liquidity premium. Schwert (2017) examines the pricing of municipal bonds with three distinct, complementary approaches to decompose municipal bond spreads into default and liquidity components. The first approach estimates the liquidity component using transaction data, the second measures the default component with credit default swap data, and the third is a quasi-natural experiment that estimates changes in default risk around pre-refunding events. Results show that default risk accounts for $74 \%$ to $84 \%$ of the average spread after adjusting for tax-exempt status. The price of default risk is high given the rare incidence of municipal default and implies a high risk premium.

IHS Markit (Markit from here onwards) as a market data provider reviewed trade and quote activity on approximately 570,000 unique municipal bonds from January 2015 through March 2016. This analysis concludes that municipal bond liquidity was stable during the period and the market was relatively efficient with intermittent periods when liquidity did taper off due to seasonal factors. A direct relationship exists between the number of unique quotes and bonds that trade on a given day or month, with the correlation almost perfectly linear during a monthly period. The number of dealers quoting a bond on a given day is correlated with the likelihood of trading. Data indicates that increasing the depth from one to four dealers increases the probability of trading from $19 \%$ to $66 \%$, based on 2015 data. There were 250 trading days in 2015 and not a single municipal bond traded every day (Markit, 2016).

Downing and Zhang (2004) found a positive relation between the number of transactions and a bond's price volatility. They also found a negative relation between average deal size and price volatility. Kalotay (2017) describes a live yield curve in the illiquid muni market, which is derived from ask prices of selected bonds across maturity spectrum.

Raman and Leidner (2018) provide a nonparametric model to estimate US municipal bond yields, which ensures that the functional relationship between the input and output variable is determined by the data rather than any a priori assumptions. The Bayesian nature of the model offers a framework to account for uncertainty in the estimates. This statistical model calculates pricing estimates based on trade transactions. Empirical analysis of the model shows that model estimates are in line with hand priced evaluations for a large number of bonds.

Chun et al. (2019) suggest an intensity-based model for pricing of municipal bonds, which simultaneously uses the credit default swap premiums of the insurers as well 
as insured and uninsured municipal bond transactions. Decomposition of municipal yield reveals a dominant role of the liquidity component as well as interactions between liquidity and default similar to those modeled by Chen et al. (2018) for corporate bonds.

Based on available literature we can see that there is no simple answer to the question, what should the price of a municipal bond be. For municipal bonds, both during primary and secondary market trading, various factors drive the price of a municipal bond. Every market participant will assign a unique price to each factor that drives the price of a municipal bond, which as a results determines final price for a municipal bond. Because every market participant has its own perception about risks associated with a municipal bond, different market participants assign different prices to the same municipal bond.

Research from Markit (2016) explains that there is no way to assess the genesis of each quote, as they are a culmination of a dealer's own inventory and trade axes from a principal perspective, as well as sell orders and client axes from an agent basis. One thing that is sure is that these quotes do not come from a vacuum and each one is sent to spur a conversation on the quoted bond or a similar bond, and these are the conversations that lead to trades.

If we are looking at bonds that are quoted and traded in the same timeframe, then we cannot assume that the dealer quoting the bond actually traded it. However, the data does indicate that the price transparency provided by the quote appears to facilitate the trade to some degree. However, market makers are an integral part of a functioning municipal bond market and the quotes they send out every day to their clients provide a gauge for several aspects of liquidity. A dealer needs to be careful about the quantity and quality of distributed quotes, as trading partners don't like to see bids too far below the market or offers well above the market. In the contrary, those same trading partners will often try to hold the trader to execute quotes, regardless of whether the levels were intentional or accidental (Markit, 2016).

Rosa (2014) has studied the impact of conventional and unconventional monetary policy on US municipal bonds. Results of his research show that monetary policy news have economically important and highly significant effects on municipal bond prices. However, prices of municipal bonds respond to monetary policy news substantially less that prices of comparable Treasury notes. This conclusion demonstrates market inefficiency because Treasury notes are risk free papers and thus react with a bigger magnitude than riskier municipal bonds. The same topic further researched Peng et al. (2014). They were researching pricing of municipal bond in stress environment. Specifically, they were comparing the yields on municipal bonds and comparable corporate bonds and found out, that municipal bonds of lower investment grade ratings after financial crisis pay a significantly higher risk premium than their corporate counterparts in light of the traditional 
yield spread between these two asset classes, which has negative implications for the municipal bond market. This is an important contribution to pricing of municipal bonds because banking regulation requires from banks to perform stress testing, which has an impact not only on pricing of municipal bonds, but ultimately also on capital requirements for market risk and total capital of the bank. Understanding of pricing of municipal bonds in stress is also important because it enables understanding of valuation results for trading portfolio of municipal bonds and because it establishes platform for development of necessary quantitative adjustments in the valuation process of municipal bonds, which is in focus of this paper. Volatility of valuation results is namely driven by volatility of underlying prices, which enter in the valuation process. As a result, it is impossible to provide appropriate explanation of valuation results on one hand and on the other hand, selection of adequate quantitative techniques within the valuation process, for any product sector, including municipal bonds.

Pricing of municipal bonds has been further researched by Mozes (2015). Specifically, he studied interest rate sensitivity of municipal bonds. He measured relative cost of municipal bonds with the difference between municipal bond yields and Treasury bond yields. Two conclusions follow from his research. The first one, the less expensive municipal bonds are relative to Treasury bonds, the lower the interest rate sensitivity of municipal bonds. And the second one, the cheaper municipal bonds are relative to Treasury bonds, the higher the return on municipal bonds, which applies after controlling for the level of municipal bond yields. Interest rate sensitivity has been studied by Kalotay and Buursma (2019). Their focus in this paper was interest rate sensitivity and effective duration for tax-exempt municipal bonds. Research shows that for tax-exempt municipal bonds, effective duration may differ from the sum of key rate durations, where key rate durations are obtained by shifting individual key rates. Research explains, that the reason for this is that the prices of discount municipal bonds are tax affected, and the applicable tax rate depends on the size of the discount.

Liu (2018) thinks about pricing of municipal bonds on the primary market, which determines the starting point for the pricing of municipal bonds on the secondary market. His study provides an estimate of the heterogeneous average treatment effect. After correcting for the endogeneity bias of sale method and its interaction effect, on average competitive sale still significantly lowers the interest rate, but the interest cost advantage decreases as issuer experience increases.

Pricing of embedded call options in municipal bonds has also been studied by many authors. Kalotay and Howard (2014) have researched the value of embedded tax options in municipal bonds. Their research has shown that under realistic assumptions, the tax option embedded in a long-term municipal bond has a value of several basis points. They proved this hypothesis based on comparison of bond prices under optimal tax management and under the unmanaged buy-and-hold base 
case. Embedded options in municipal bonds have also been studied by Gurwitz et al. (1992). They show that embedded option in municipal bonds has a different value for investors and for issuers on the municipal market. Specifically, ability to evaluate after tax cash flows and the effect of a potential advance refunding on the value of a municipal bond in the secondary market are not relevant capabilities of the valuation model from the perspective of issuers. Taxation of municipal bonds have studied Yerkes at al. (2016). Their paper analyzes an extensive sample of tax-exempt and taxable municipal bonds and studies how municipal bonds behave without federal tax exemption. The authors find that taxable municipal bonds are issued at higher yields in high state tax jurisdictions and that they are less likely to be issued in these areas and more likely to be issued in those that tax in-state issues.

Pricing is the starting point of the valuation process to calculate pricing adjustments, and literature review above demonstrates that it has been researched extensively. However, authors so far have not researched much valuation models to calculate pricing adjustments for municipal bonds. As a result, available literature offers very little researches of valuation models and very little improved approaches for calculation of pricing adjustments, which are ultimately booked in the general ledger of the portfolio holder. We can find limited contribution to price testing of municipal bonds in Lai and Zhang (2013). They used a large sample of US municipal bond data from 2001 to 2010 and studied the time variation of the value of municipal bond insurance, estimated with differentials in yields between insured and uninsured municipal bonds at issue. Their research shows that the supply of bonds and the level of market interest rates to have significant positive impacts on the time-varying value of bond insurance. Their research further shows asymmetric response of yield differentials to rises and declines of market interest rates. Research also shows that the value of municipal bond insurance is not a function of business cycles, but rather a function of habitat preference of municipal bonds issues. Methodological approach in this paper compares yields of insured and uninsured municipal bonds, where yields of uninsured municipal bonds serve as benchmark yields. Comparison of yields is typical for price testing. However, this paper does not discuss the number of different pricing sources to calculate the yields of insured and uninsured municipal bonds, which enter into the research. This paper also does not discuss methodological approach and does not offer an improved methodological approach, which would contribute to development of price testing for municipal bonds.

We were able to find one more paper in the exiting economic literature, which discusses elements of the price testing process for municipal bonds. This is research from Stock (1982). He empirically analyzed municipal bond portfolio structure and performance. On the back of this research, he was able to conclude that the prime determinants of price volatility are maturity and risk-premium. This paper studied municipal bonds not on individual level, but on the portfolio level, which is the 
ultimate purpose of the price testing process. However, also this paper does not put in focus the number of pricing services to determine performance of the municipal bond portfolio nor discusses existing price testing techniques to calculate pricing adjustments for municipal bonds.

As a result, we conclude that available literature does not discuss the number of pricing services to calculate the benchmark price for municipal bonds nor discusses existing price testing techniques to calculate pricing adjustments for municipal bonds.

\section{Methodology}

Price testing process starts with calculation of the pre-threshold pricing adjustment. Assume $w$ is the pre-threshold pricing adjustment for a municipal bond, $n$ is the current notional value, $p_{i}$ is the internal or front office price and $p_{b}$ is the benchmark or consensus price for the same municipal bond. Then the pre-threshold pricing adjustment $w$ for a municipal bond is defined with the following equation:

$$
w=n \cdot \frac{p_{i}-p_{b}}{100}
$$

Price testing thresholds are implemented to distinguish between price variances due to market noise or vendor price quality and actual valuation disparity between front office and consensus levels. They are defined based on product sector attributes and prevailing market conditions (liquidity, risk leverage, price clarity, etc.), including bid-offer levels. Assume $x$ is the post-threshold pricing adjustment for a municipal bond and $t$ is the pricing threshold, then the post-threshold pricing adjustment $x$ for a municipal bond is defined with the following equation:

$$
x=\left\{\begin{array}{c}
n \cdot \frac{\left|p_{i}-p_{b}\right|-t}{100} \cdot \frac{p_{i}-p_{b}}{\left|p_{i}-p_{b}\right|} ; n \cdot \frac{\left(\left|p_{i}-p_{b}\right|-t\right)}{100}>0 \\
0 ; n \cdot \frac{\left(\left|p_{i}-p_{b}\right|-t\right)}{100} \leq 0
\end{array}\right.
$$

On the portfolio level with $m$ CUSIPs in the portfolio is post-threshold pricing adjustment $x_{p}$ so:

$$
x_{p}=\sum_{j=1}^{m}\left[n_{j} \cdot \frac{\left|p_{i j}-p_{b j}\right|-t_{j}}{100} \cdot \frac{p_{i j}-p_{b j}}{\left|p_{i j}-p_{b j}\right|}\right] ; n_{j} \cdot \frac{\left|p_{i j}-p_{b j}\right|-t_{j}}{100}>0
$$

The valuation control function does not need to include additional pricing service in the calculation of the final consensus price if this additional pricing service does not bring additional pricing information. To find out if Bloomberg brings 
additional pricing information to the benchmark price or not, we will use NY3PM bid prices and for each CUSIP and calculate two different benchmark prices. The first benchmark price $p_{b}(2 \mathrm{~V})$ will include two vendors, Markit and IDC. The second benchmark price $p_{b}(3 V)$ will include three vendors, Markit, IDC and Bloomberg. Each benchmark price will be calculated as a median. Both medians will be in the following relationship for each CUSIP $j$ :

$$
p_{b j}(3 V)=p_{b j}(2 V)+\varepsilon_{j}
$$

where $\varepsilon_{j}$ represents a deviation from the benchmark price, which is calculated based on two vendors only. To measure average quantity of additional pricing information on the portfolio level, which enters into the benchmark price with additional pricing service, we will calculate mean absolute deviation of $\varepsilon_{j}$, where $j \in\{1,2, \ldots, m\}$ and $m$ is the number of CUSIPs in the portfolio.

This mean absolute deviation $\delta_{p}$ is defined as follows:

$$
\delta_{p}=\frac{1}{m} \sum_{j=1}^{m}\left|\varepsilon_{j}\right|=\frac{1}{m} \sum_{j=1}^{m}\left|p_{b j}(3 V)-p_{b j}(2 V)\right|=\frac{1}{m} \sum_{j=1}^{m}\left|\varphi_{j}(3 V)-\varphi_{j}(2 V)\right|
$$

Assume that the valuation control function considers all relevant vendors as equally important price contributors, then the control valuation function will calculate the benchmark or consensus price to enter the price testing process as the median price. In case of final set of ascendingly ordered numbers $X=\left\{x_{1}, x_{2}, \ldots, x_{n}\right\}$, the median $\varphi$ is defined as follows:

$$
\varphi=\left\{\begin{array}{c}
\frac{x_{n+1}}{2} ; n \text { is an odd number } \\
\frac{x_{\frac{n}{2}}+x_{\frac{n+2}{2}}}{2} ; n \text { is an even number }
\end{array}\right.
$$

We know that a post-threshold pricing adjustment with benchmark price as a median from two vendors $x_{p}(2 V)$ and for portfolio with $m$ CUSIPs is:

$$
\begin{aligned}
& x_{p}(2 V)=\sum_{j=1}^{m}\left[n_{j} \cdot \frac{\left|p_{i j}-p_{b j}(2 V)\right|-t_{j}}{100} \cdot \frac{p_{i j}-p_{b j}(2 V)}{\left|p_{i j}-p_{b j}(2 V)\right|}\right] \\
& n_{j} \cdot \frac{\left|p_{i j}-p_{b j}(2 V)\right|-t_{j}}{100}>0
\end{aligned}
$$

We also know that $p_{b j}(2 V)=p_{b j}(3 V)-\varepsilon_{j}$.

For $j \in\{1,2, \ldots, m\}$ and $n_{j} \cdot \frac{\left|p_{i j}-\left(p_{b j}(3 V)-\varepsilon_{j}\right)\right|-t_{j}}{100}>0$ therefore holds: 


$$
\begin{aligned}
& x_{p}(2 V)=\sum_{j=1}^{m}\left[n_{j} \cdot \frac{\left|p_{i j}-\left(p_{b j}(3 V)-\varepsilon_{j}\right)\right|-t_{j}}{100} \cdot \frac{p_{i j}-\left(p_{b j}(3 V)-\varepsilon_{j}\right)}{\left|p_{i j}-\left(p_{b j}(3 V)-\varepsilon_{j}\right)\right|}\right] \\
& x_{p}(2 V)=\sum_{j=1}^{m}\left[n_{j} \cdot \frac{\left|\left(p_{i j}-p_{b j}(3 V)\right)+\varepsilon_{j}\right|-t_{j}}{100} \cdot \frac{\left(p_{i j}-p_{b j}(3 V)\right)+\varepsilon_{j}}{\left|\left(p_{i j}-p_{b j}(3 V)\right)+\varepsilon_{j}\right|}\right]
\end{aligned}
$$

Post-threshold pricing adjustment with benchmark price as a median from three vendors $x_{p}(3 V)$ and for portfolio with $m$ CUSIPs is:

$$
\begin{aligned}
& x_{p}(3 V)=\sum_{j=1}^{m}\left[n_{j} \cdot \frac{\left|p_{i j}-p_{b j}(3 V)\right|-t_{j}}{100} \cdot \frac{p_{i j}-p_{b j}(3 V)}{\left|p_{i j}-p_{b j}(3 V)\right|}\right] ; \\
& n_{j} \cdot \frac{\left|p_{i j}-p_{b j}(3 V)\right|-t_{j}}{100}>0
\end{aligned}
$$

Impact of additional pricing information from additional vendor on the postthreshold pricing adjustment is equal to a difference between post-threshold pricing adjustments from three and two vendors:

$$
\Delta=x_{p}(3 V)-x_{p}(2 V)
$$

For $j \in\{1,2, \ldots, m\}$ and $n_{j} \cdot \frac{\left|p_{i j}-p_{b j}\right|-t_{j}}{100}>0$ holds:

$$
\begin{aligned}
\Delta= & x_{p}(3 V)-x_{p}(2 V) \\
\Delta= & \sum_{j=1}^{m}\left[n_{j} \cdot \frac{\left|p_{i j}-p_{b j}(3 V)\right|-t_{j}}{100} \cdot \frac{p_{i j}-p_{b j}(3 V)}{\left|p_{i j}-p_{b j}(3 V)\right|}\right]- \\
& -\sum_{j=1}^{m}\left[n_{j} \cdot \frac{\left|\left(p_{i j}-p_{b j}(3 V)\right)+\varepsilon_{j}\right|-t_{j}}{100} \cdot \frac{\left(p_{i j}-p_{b j}(3 V)\right)+\varepsilon_{j}}{\left|\left(p_{i j}-p_{b j}(3 V)\right)+\varepsilon_{j}\right|}\right] \\
\Delta= & \frac{1}{100} \sum_{j=1}^{m}\left[\frac{n_{j} \cdot\left(\left|p_{i j}-p_{b j}(3 V)\right|-t_{j}\right) \cdot\left(p_{i j}-p_{b j}(3 V)\right)}{\left|p_{i j}-p_{b j}(3 V)\right|}-\right. \\
& \left.-\frac{n_{j} \cdot\left(\left|p_{i j}-p_{b j}(2 V)\right|-t_{j}\right) \cdot\left(\left(p_{i j}-p_{b j}(3 V)\right)+\varepsilon_{j}\right)}{\left|p_{i j}-p_{b j}(2 V)\right|}\right]
\end{aligned}
$$




$$
\begin{aligned}
& \Delta=\frac{1}{100} \sum_{j=1}^{m}\left[\frac{n_{j} \cdot\left(\left|p_{i j}-p_{b j}(3 V)\right|-t_{j}\right) \cdot\left(p_{i j}-p_{b j}(3 V)\right) \cdot\left|p_{i j}-p_{b j}(2 V)\right|}{\left|p_{i j}-p_{b j}(3 V)\right| \cdot\left|p_{i j}-p_{b j}(2 V)\right|}-\right. \\
& \left.-\frac{n_{j} \cdot\left(\left|p_{i j}-p_{b j}(2 V)\right|-t_{j}\right) \cdot\left(\left(p_{i j}-p_{b j}(3 V)\right)+\varepsilon_{j}\right) \cdot\left|p_{i j}-p_{b j}(3 V)\right|}{\left|p_{i j}-p_{b j}(3 V)\right| \cdot\left|p_{i j}-p_{b j}(2 V)\right|}\right] \\
& \Delta=\frac{1}{100} \sum_{j=1}^{m}\left[n_{j} \cdot \frac{\left(p_{i j}-p_{b j}(3 V)\right)}{\left|p_{i j}-p_{b j}(3 V)\right| \cdot *\left|p_{i j}-p_{b j}(2 V)\right|}\right. \\
& \cdot\left[\left(\left|p_{i j}-p_{b j}(3 V)\right|-t_{j}\right) \cdot\left|p_{i j}-p_{b j}(2 V)\right|-\left(\left|p_{i j}-p_{b j}(2 V)\right|-t_{j}\right) .\right. \\
& \left.\left.\cdot\left|p_{i j}-p_{b j}(3 V)\right|+\frac{\left(\left|p_{i j}-p_{b j}(2 V)\right|-t_{j}\right) \cdot\left|p_{i j}-p_{b j}(3 V)\right| \cdot \varepsilon_{j}}{\left(p_{i j}-p_{b j}(3 V)\right)}\right]\right] \\
& \Delta=\frac{1}{100} \sum_{j=1}^{m}\left[\frac{n_{j}}{\left|p_{i j}-p_{b j}(3 V)\right| \cdot\left|p_{i j}-p_{b j}(2 V)\right|} .\right. \\
& \cdot\left[\left(\left|p_{i j}-p_{b j}(3 V)\right|-t_{j}\right) \cdot\left|p_{i j}-p_{b j}(2 V)\right| \cdot\left(p_{i j}-p_{b j}(3 V)\right)-\right. \\
& \left.\left.-\left(\left|p_{i j}-p_{b j}(2 V)\right|-t_{j}\right) \cdot\left|p_{i j}-p_{b j}(3 V)\right| \cdot\left[\left(p_{i j}-p_{b j}(3 V)\right)+\varepsilon_{j}\right]\right]\right]
\end{aligned}
$$

\section{Empirical data and analysis}

Various external financial market data institutions (vendors) provide prices for US municipal bonds, which enter as external prices into the price testing process. They enter as benchmark of fair value for inventoried positions in the trading portfolio. The choice of vendors utilized as part of the price testing process is largely driven by the valuation control function's consideration of their valuation capabilities and their market coverage. The major leading institutions providing such evaluation services are Markit and IDC, both of whom are considered industry experts in providing muni bond analysis. Markit provides quotes for more than 1,1 million municipal bonds rated Aaa/AAA to Baa3/BBB- with both fixed and variable coupons. Pricing inputs include data from proprietary parsing technology and the Municipal Securities Rulemaking Board (MSRB) feed. Quotes incorporate also the 
financial condition of each state and municipality, uses of proceeds and other issue level factors (Markit, 2016).

There are various pricing services that each vendor provides for the same product sector. Prices are first location specific to consolidate opinions of market value from local market participants. Vendors provide prices for all market orientations, which are bid, ask and mid prices. Finally, vendors may also provide prices at different cut-off times during a business day. Each vendor provides at least close price at the end of the business day, but it can also provide prices for other cut-off times during the business day.

Key requirement in the price testing process is that all pricing services utilized refer to the same cut-off time, which ensures that valuation results and corresponding pricing adjustments belong to one snapshot. The price testing process utilizes bid prices to calculate the amount of money front office would get if it would sell all portfolio at selected cut-off time. As a result, all external prices imported and used in the price testing process are also bid-side prices to ensure proper price comparison.

The financial control function will leverage those location specific prices from vendors, which match up with location of the portfolio. If portfolio resides in the US, the financial control function will use New York prices.

For municipal bonds, IDC provides prices for New York location only once per day. These are New York close prices, which reflect prices at 3pm New York time. Business acronym for these prices is NYCLOSE prices. Markit on the other hand provides two price snapshots each day for municipal bonds, these are New York $3 \mathrm{pm}$ (NY3PM) and New York 4pm (NY4PM) prices. Because snapshots from all vendors in the price testing process must match up and because IDC provides prices for municipal bonds only at $3 \mathrm{pm}$ New York time, the valuation control function will select NY3PM market prices.

Beside IDC and Markit, Bloomberg also provides prices each business day for US municipal bonds. The relevant Bloomberg pricing service that provides prices of US municipal bonds is Bloomberg Valuation Service (BVAL). BVAL is an endof-day evaluated pricing service covering 2,5 million fixed income bonds and loans. It covers also thinly-traded and hard-to-price fixed income securities. All BVAL prices are independent, transparent and defendable, with the majority being model derived. Inputs include reported trades and contributed quotes contracted specifically with BVAL (Bloomberg L.P., 2016a).

Market coverage and pricing integrity of BVAL prices enable portfolio holder valuation of fixed income portfolios, but also ensures that entire organization of the portfolio holder, from front office to back office, has consistent access to the same pricing service (Bloomberg L.P., 2015). 
Fixed income markets have evolved dramatically over the last few decades with the introduction of streaming quotes, electronic trading and more compliance and regulatory requirements. To help market participants keep up with this demanding environment, Bloomberg provides more pricing data, more often and with more transparency for government, supranational, agency and corporate (GSAC) bonds, municipal bonds and securitized products (Bloomberg Finance L.P., 2020).

BVAL uses pricing data from only the highest quality market contributors. These include TRACE, MSRB, exchanges and broker quotes. Collected data enter into a data review process, which filters, cleanses and verifies pricing data further for ongoing quality and consistency. Capital markets experts monitor the process of data collection and provide exceptional 24/5 global and around the clock customer service. Result enables Bloomberg to provide prices and valuations, which are highly accurate and defensible, so users can act upon it with confidence (Bloomberg Finance L.P., 2020).

Market of municipal bonds at Bloomberg oversees a team of experts for municipal bond with market experience. BVAL prices for municipal bonds consistently demonstrate the lowest degree of tracking error and the highest degree of transparency in the industry. For securities that are less liquid, among them are also US municipal bonds, BVAL derives a comparable relative price with an algorithm based on the most recent market data. Therefore, BVAL prices are reactive and closely reflect current market conditions (Bloomberg Finance L.P., 2020).

Bloomberg prices are supported by the BVAL score, a proprietary metric designed to give insight into the amount and consistency of market data used to produce the BVAL price. The metric utilizes Bloomberg's ability to access a wealth of market observations and the standard deviation of those observations. It is defined on a scale between 1-10. Direct market observations sourced from the Bloomberg Trading System, TRACE, MSRB, and other permissioned contributions get maximum score of 10 . When direct observations on the target fixed income instrument are insufficient, observations on comparable fixed income instruments are leveraged to determine a relative price of the target fixed income instrument. Such fixed income instruments receive a BVAL score of 5 or lower and are priced using mostly data from comparable securities rather than direct observations on the target fixed income instrument (Bloomberg L.P., 2016b).

The BVAL score has been designed to identify securities with limited availability of pricing data, which is especially important in the price testing process at portfolio holder. Valuable characteristic of the BVAL score is also its consistency across asset classes in the universe of asset classes that Bloomberg covers. The BVAL score has namely been calibrated to be consistent across all asset classes depending on the data used to produce the BVAL score (Bloomberg L.P., 2015). 
The BVAL score is not a statement of accuracy, relative quality or an indicator of confidence in the BVAL price. Bloomberg as a vendor is confident in the quality of BVAL prices and believes that they are defensible. Further, the BVAL score is also not a liquidity indicator even though it is possible that securities with higher BVAL scores have more market makers providing prices. If a user is able to access those market makers, he may find more liquidity for those securities with higher BVAL scores as opposed to ones that have lower BVAL scores. As a result, BVAL score enhances the valuation process, for which valuation control function of the portfolio owner is responsible for (Bloomberg L.P., 2015).

BVAL pricing data are available on the Bloomberg Terminal or as an enterprise data feed via Bloomberg Data License. On the Bloomberg Terminal, BVAL pricing service is integrated into Bloomberg's Asset \& Investment Manager (AIM), Trade Order Management Solutions (TOMS), Portfolio Management System (PORT) and regulatory and accounting products (Bloomberg Finance L.P., 2020).

Bloomberg provides two snapshots per day for US municipal bonds, these are New York $3 \mathrm{pm}$ and $4 \mathrm{pm}$ prices. Because Bloomberg also provides pricing services for US municipal bonds, the question appears if the valuation control function should also use this pricing service in the price testing process.

To answer the question, we will use a trading portfolio of US municipal bonds in the balance sheet of a financial institution in USA as of 29 March 2019. This portfolio contained high-grade as well as high-yield US municipal bonds with total market value as per front office or internal prices of $1,55 \mathrm{bn}$ USD. There were 279 unique CUSIPs in the portfolio.

For each CUSIP in the portfolio, we collected NY3PM bid prices on 29 March 2019 from all three vendors in focus, which are Markit, IDC and Bloomberg. After importing the prices from vendors, we reviewed imported prices. Review has shown that all three vendors provided a price for each CUSIP in the portfolio, which demonstrates that each vendor holds sufficient market coverage. Sufficient market coverage in return enables the vendor to quote prices for locations, market orientations and time snapshots. According to this criteria, we cannot identify a vendor, who would provide less reliable prices as other vendors. As a result, we can consider all three vendors as equally important.

\section{Results and discussion}

We measured an average quantity of additional pricing information on the portfolio level, which enters into the consensus price with additional pricing service, with mean absolute deviation. Mean absolute deviation of the difference between consensus price with three vendors and consensus price with two vendors was $\delta_{p}=$ 
0,22683 index points. As a result, we can conclude that additional pricing service does bring additional pricing information to the final consensus or benchmark price. We can further conclude that the valuation control function should consider this additional pricing service as a relevant vendor for calculation of the consensus price, which enters as a benchmark price into the price testing process. To conclude if the valuation control function should also use this pricing service in the price testing process on a regular basis, we should calculate statistical significance of this difference, which supersedes the purpose of this paper.

To calibrate the impact of additional pricing information on final price testing results, we calculated a difference between post-threshold pricing adjustment, where the benchmark price contained three vendors, and post-threshold pricing adjustment, where the benchmark price contained two vendors. Calculation has shown a difference of -595.363 USD. Post-threshold pricing adjustment with benchmark price from two vendors was 720.795 USD, therefore we can conclude that the additional pricing information significantly changes post-threshold pricing adjustment.

This is a difference between post-threshold pricing adjustments for one monthend in a year. If we would observe equal result each month, which is a reasonable assumption if these are price testing results in normal circumstances on financial markets, then we would be able to conclude that it is likely to see similar price volatility also in the next months as long as situation on financial markets does not change. As a result, estimated difference between post-threshold pricing adjustments at a yearly level is $12 \cdot(-595.363 \mathrm{USD})=-7.144 .356 \mathrm{USD}$, which is a significant amount and has a material impact on final profit and loss of the portfolio holder and ultimately on the market value of shareholder's equity.

From the shareholder's perspective is introduction of additional pricing service in the calculation of the benchmark price economically justified if it is estimated difference between post-threshold pricing adjustments at a yearly level higher than the yearly cost of additional pricing service. Because it is estimated difference between post-threshold pricing adjustments at a yearly level -7.144.356 USD and much higher than the yearly cost of additional pricing service, is therefore from perspective of shareholders economically justified to include this pricing service in the calculation of the benchmark price.

It is not only in interest of shareholders to reflect a trading portfolio of municipal bonds at fair value, this is also in interest of banking regulators. Valuation of a trading portfolio with municipal bonds at fair value enables correct calculation of capital charges for market risk from positions in the trading portfolio with municipal bonds. Moreover, it also enables correct calculation of capital adequacy of a bank. Capital adequacy is a key metric of banking solvency, which may be endangered in times of stress due to reduced prices of US municipal bonds on 
financial markets. Incomplete inclusion of pricing services in the benchmark price may leave out important pricing information from another vendor and may lead to overpriced benchmark price, which enters in the price testing process, and it ultimately leads to overpriced total market value of the trading portfolio in comparison to actual situation on financial markets. In this case, capital of a bank may appear as adequate, which would not be the case if the benchmark price would contain all relevant pricing information from the market and consequently, all relevant pricing services from all vendors. As a result, the benchmark price without additional pricing service may require capital increase from the bank later than informationally holistic benchmark price with additional pricing service. Previous financial crisis has shown, that collection of capital in times of stress is more demanding than in normal times on financial markets. Hence it is better for the bank to collect capital before crisis, which may be in crisis not only too late, but also impossible.

To avoid incomplete reflection of pricing adjustments in the general ledger, the valuation control function should holistically identify vendors on the market that provide external prices for municipal bonds and assess amount of additional pricing information from each external price to the benchmark price. The valuation control function should keep adding additional pricing services to the benchmark price as long as contribution from additional pricing service to price testing results is significant. When contribution of additional pricing service to the benchmark or consensus price and ultimately to the pricing adjustment becomes insignificant, the valuation control function does not need to add this additional pricing service to the benchmark price.

\section{Conclusion}

In this paper we have explored impact of partial pricing information from additional pricing service in the benchmark price on post-threshold pricing adjustments. We have measured this impact with the difference between the post-threshold pricing adjustment with additional pricing service and post-threshold pricing adjustment without additional pricing service in the benchmark price. Our research shows that in case of very small number of pricing services in the benchmark price, additional pricing service brings material new information to calculation of the benchmark price, which enters into the price testing process of US municipal bonds. As a result, we have also shown that that introduction of additional pricing service in the calculation of the benchmark price is economically justified when the pricing adjustment with additional external price is materially different from the pricing adjustment without additional external price, which proves our working hypothesis. We see this result from our research as a new contribution to economic science. Measurement of additional pricing information is a responsibility of the valuation 
control function at establishment of a portfolio and before the first calculation of the pricing adjustment. As we can see from results, consideration to include additional pricing service in calculation of the benchmark price is necessary and management of the valuation control function should implement it in the business process.

Approach and results in this paper have two limitations. The first one is shallowness of external price by CUSIP in the pricing service. Even if vendors provide price for a CUSIP, this price may be calculated on a shallow pool of market participants, which moves this price further away from market average and therefore makes it less useful for calculation of the benchmark price. Vendors may not explain, how many market participants they used to calculate external price for a CUSIP, in which case we can conclude about reliability of a pricing service. As we have explained, Bloomberg provides a proprietary metric as an indicator of the amount and consistency of market data used to produce the BVAL pricing service. This is the BVAL score, which accompanies and supports the BVAL price. Other vendors may have other metrics, which serve the same purpose. Even though Bloomberg calibrated this metric to be consistent across all asset classes depending on the data used to calculate the BVAL pricing service, the definition of the BVAL score may not be the same as definition of similar metrics at other vendors, which disables comparison of shallowness among pricing services from different vendors. Further, vendors typically do not provide granular data, which they used to calculate their metric of market shallowness. Availability of granular data of market coverage would allow to research the universe of market observations, which is available to each vendor and based on which each vendor calculates its metric of market shallowness. Shallowness of pricing services may result in an unlikely situation, where alteration of the benchmark price after inclusion of additional pricing service is driven by a shallow pool of market participants with limited opinion about fair value of an asset in focus and not by a reliable additional information about the market price. As a result, the difference between post-threshold pricing adjustment with additional pricing service and post-threshold pricing adjustment without additional pricing service may appear material, which in reality is not true and would be an incorrect conclusion about fair value of assets in the trading portfolio.

The second limitation is applicability of results from this research after inception of the trading portfolio. The results of this research are not sufficient to make a conclusion whether the significance of additional information from additional pricing service in the benchmark price is variable in time of normal circumstances on financial markets. Hence, results of this research are not able to advise whether the valuation control function should measure informational contribution of pricing services to the benchmark price within the lifetime of the portfolio. Also this question oversteps the purpose of this research and remains an open question to explore in the future. 


\section{References}

Bloomberg L.P. (2015) "Pricing data", Available at: $<$ https://www.bbhub.io/solutions/ sites/8/2015/10/BVAL-Score-fact-sheet.pdf>, [Accessed: June 7, 2020].

Bloomberg L.P. (2016a) "Fixed income cash pricing sources", Available at: $<$ https://data.bloomberglp.com/professional/sites/10/Fixed-Income-CashPricing-Sources.pdf>, [Accessed: July 27, 2019].

Bloomberg L.P. (2016b) "Index methodology global fixed income", Available at: $<$ https://data.bloomberglp.com/indices/sites/2/2015/12/GFI_Index_Family_ Methodology.pdf>, [Accessed: June 7, 2020].

Bloomberg Finance L.P. (2020) "Pricing data", Available at: $<$ https://www. bloomberg.com/professional/product/pricing-data/>, [Accessed: June 7, 2020].

Chen, H., Cui, R., He, Z., Milbradt, K. (2018) "Quantifying liquidity and default risks of corporate bonds over the business cycle", The Review of Financial Studies, Vol. 31, No. 3, pp. 852-897, https://doi.org/10.1093/rfs/hhx107.

Chun, A. L., Namvar, E., Ye, X., Yu, F. (2019) "Modeling Municipal Yields with (and without) Bond Insurance", Management Science, Vol. 65, No. 8, pp. 3694 3713, https://doi.org/10.1287/mnsc.2017.3007.

Downing, C., Zhang, F. (2004) "Trading activity and price volatility in the municipal bond market", Journal of Finance, Vol. 59, No. 2, pp. 899-931, https://doi.org/10.1111/j.1540-6261.2004.00652.x.

Fama, E. F. (1977) A pricing model for the municipal bond market, Unpublished manuscript, University of Chicago.

Gurwitz, A. S., Knez, P., Wadhwani, S. (1992) "A valuation model for embedded options in municipal bonds", The Journal of Fixed Income, Vol. 2, No. 1, pp. 102-111, https://doi.org/10.3905/jfi.1992.408038.

Kalotay, A. (2017) "Creating a live yield curve in the illiquid muni market", The Journal of Fixed Income, Vol. 27, No. 1, pp. 84-91, https://doi.org/10.3905/ jfi.2017.27.1.084.

Kalotay, A., Buursma, J. (2019) "The key rate durations of municipal bonds", The Journal of Fixed Income, Vol. 29, No. 2, pp. 61-64, https://doi.org/10.3905/ jif.2019.1.073.

Kalotay, A., Howard, C. D. (2014) "The Tax Option in Municipal Bonds", The Journal of Portfolio Management, Vol. 40, No. 2, pp. 94-102, https://doi. org/10.3905/jpm.2014.40.2.094.

Kriz, K. A. (2004) "Risk Aversion and the Pricing of Municipal Bonds", Public Budgeting Finance, Vol. 24, No. 2, pp. 74-87, https://doi.org/10.1111/j.0275-1100. 2004.02402005.x.

Lai, V. S., Zhang, X. (2013) "On the value of municipal bond insurance: an empirical analysis", Financial Markets, Institutions \& Instruments, Vol. 22, No. 4, pp. 209-228, https://doi.org/10.1111/fmii.12010. 
Lin, H., Liu, S., Wang, J., Wu, C. (2010) "Liquidity and the Pricing of Municipal Bonds". In Proceedings of the 2010 China International Conference in Finance, Beijing, China. Available at: <http://citeseerx.ist.psu.edu/viewdoc/download?d oi=10.1.1.599.3626\&rep=rep1\&type=pdf $>$, [Accessed: August 3, 2019].

Litvack, D., Rizzo, F. (2000) "Municipal default risk", Municipal Finance Journal, Vol. 21, No. 2, pp. 25-42.

Liu, G. (2018) "The Effect of Sale Methods on the Interest Rate of Municipal Bonds: A Heterogeneous Endogenous Treatment Estimation", Public Budgeting \& Finance, Vol. 38, No. 2, pp. 81-110, https://doi.org/10.1111/pbaf.12174.

Markit (2016) Measuring municipal bond market liquidity. Special Report: Measuring municipal bond market liquidity. Available at: < https://ihsmarkit. com/research-analysis/09052016-Credit-Measuring-municipal-bond-marketliquidity.html>, [Accessed: August 3, 2019].

Markit (2016) Markit fixed income pricing. Available at: $<$ https://cdn.ihs.com/ www/pdf/Pricing-Data-Bonds.pdf>, [Accessed: August 4, 2019].

Mozes, H. A. (2015) "The time-varying interest rate sensitivity of municipal bonds", The Journal of Wealth Management, Vol. 18, No. 2, pp. 47-54, https:// doi.org/10.3905/jwm.2015.18.2.047.

Partridge, C., Medda, F. R. (2020) "The evolution of pricing performance of green municipal bonds", Journal of Sustainable Finance \& Investment, Vol. 10, No.1, pp. 44-64, https://doi.org/10.1080/20430795.2019.1661187.

Peng, J., Kriz, K., Wang, Q. (2014) "The Two Worlds of Municipal Bonds: Are Lower-Rated Bonds Punished More by Financial Crisis?", Public Budgeting \& Finance, Vol. 34, No. 1, pp. 18-38, https://doi.org/10.1111/pbaf.12028.

Raman, N., Leidner, L. L. (2018) "Municipal bond pricing: a data driven method", International Journal of Financial Studies, Vol. 6, No. 3, pp. 80-99, https://doi. org/10.3390/ijfs6030080.

Rosa, C. (2014) "Municipal Bonds and Monetary Policy: Evidence from the Fed Funds Futures Market", Journal of Futures Markets, Vol. 34, No. 5, pp. 434450, https://doi.org/10.1002/fut.21606.

Schwert, M. (2017) "Municipal Bond Liquidity and Default Risk", Journal of Finance, Vol. 72, No. 4, pp. 1683-1722, https://doi.org/10.1111/jofi.12511.

Wang, J., Wu, C., Zhang, F. X. (2008) "Liquidity, default, taxes, and yields on municipal bonds", Journal of Banking \& Finance, Vol. 32, No. 6, pp. 11331149, https://doi.org/10.1016/j.jbankfin.2007.09.019.

Yerkes, R. T., Bates, L., McCarty, S. H. (2016) "How Do Municipal Bonds Behave without Tax Exemption?", The Journal of Investing, Vol. 25, No. 4, pp. 51-63, https://doi.org/10.3905/joi.2016.25.4.051. 


\title{
Integritet referentne cijene za testiranje cijena američkih općinskih obveznica
}

\author{
Srečko Devjak ${ }^{1}$
}

\begin{abstract}
Sažetak
Vanjske institucije koje raspolažu podacima o financijskim tržištima (dobavljači) mogu za istu američku municipalnu obveznicu ponuditi različite cijene zbog razlika u percepciji njihove tržišne vrijednosti među sudionicima na tržištu. Funkcija kontrole procjene uključivat će samo odabrane dobavljače u izračun dogovorne cijene, koja ulazi kao referentna cijena u postupku testiranja cijena. Odabir dobavljača u velikoj je mjeri vođen razmatranjem funkcije kontrole procjene o njihovoj sposobnosti vrednovanja i njihove prisutnosti na tržištu. Empirijska analiza u ovom radu pokazuje da dodatna cjenovna usluga može dati dodatne informacije o tržišnim cijenama do finalne cijene postignute konsenzusom, što može značajno promijeniti referentnu cijenu i konačne rezultate cijenovnog testiranja. Pristup opisan u ovom radu koristan je za financijske institucije s američkim municipalnim obveznicama u trgovinskom portfelju. Doprinos ovog rada o vrednovanju američkih municipalnih obveznica je značajan budući da dosadašnja literatura ne objašnjava alternativni pristup mjerenju dodatnih cjenovnih informacija o referentnoj cijeni.
\end{abstract}

Ključne riječi: investicijsko bankarstvo, američke municipalne obveznice, upravljanje rizikom procjene vrijednosti, tržišna učinkovitost, izračun referentne cijene

JEL klasifikacija: G12, G14, G24, G32, C81

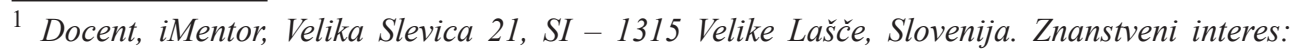
treasury risk management in banking, quant engineering in banking. Phone: +38640850090 . E-mail: dr.S.Devjak@gmail.com. Osobna web stranica: https://www.linkedin.com/in/drsrecko-devjak-83048025\%. 